\title{
Kerumitan Kalimat Bahasa Indonesia Siswa Autis
}

\author{
Astri Widyaruli Anggraeni \\ Program Studi Pendidikan Bahasa dan Sastra Indonesia \\ Universitas Muhammadiyah Jember \\ astriwidyaruli@unmuhjember.ac.id \\ DOI: https://doi.org/10.32528/bb.v6i2.4972
}

First received: 26-06-2021

Final proof received: $18-10-2021$

\begin{abstract}
ABSTRAK
Tata Bahasa Semesta diyakini oleh para ahli bahasa sebagai piranti belajar bahasa pada anak yang dapat mengembangkan pemerolehan bahasanya. Penelitian ini mengkaji dan mengeksplanasikan kerumitan kalimat bahasa Indonesia siswa autis yang dibangun dengan inti leksikal. Hasil yang didapatkan adalah siswa autis mengembangkan kerumitan kalimat dengan menggunakan inti leksikal verba dengan pola tanpa komplemen, inti leksikal verba dengan adanya argumen dalam, inti leksikal dengan keterangan tambahan frase preposisi, dan koordinasi verba berpalang satu (V' coordination). Pada inti leksikal adjektiva berupa kalimat tanpa argumen yang berproyeksi maksimal dan diproyeksikan langsung ke proyeksi maksimal (FAdj). Kalimat tersebut dianalisis menggunakan skema X-Bar sebagai salah satu model TBPI (Government and Binding).

Kata Kunci: kalimat; autis; teori X-Bar
\end{abstract}

\begin{abstract}
Universal Grammar developed by linguists as a language learning tool in children who can develop language acquisition. This study will examine and explain the complexity of students' sentences in Indonesian which are built with a lexical core. The results obtained are students with autism develop sentence complexity by using lexical core verbs with patterns without complements, lexical core verbs with internal arguments, lexical cores with additional prepositional phrases, and one-crossed verb coordination ( $\mathrm{V}^{\prime}$ coordination). At the core of lexical adjectives are sentences without arguments that have maximum and direct projections to maximum projections (FAdj). These sentences were analyzed using the XBar scheme as one of the TBPI (Government and Binding) models.
\end{abstract}

Key words: Sentence; Autism; X-Bar theory 


\section{PENDAHULUAN}

Penelitian yang banyak dilakukan dalam ruang lingkup kelas kebanyakan dilakukan untuk menggambarkan apa yang terjadi di kelas, seperti tingkah laku guru dan siswa, pengukuran hasil belajar siswa, dan metode atau strategi guru mengajar yang sangat substansial. Penelitian belum terfokus pada 'apa yang dihasilkan siswa' untuk dapat digunakan sebagai panduan atau petunjuk yang dapat digunakan guru dalam mengajar. Misalkan saja mengenai pemerolehan bahasa anak yang harus diketahui dengan mendasarkan pada jenjang kelas dan usia, di mana hasilnya akan memberikan kontribusi untuk penyusunan kurikulum, silabus materi, media pembelajaran yang sesuai dengan pemerolehannya. Hasil-hasil penelitian tersebut kemudian disintesiskan menjadi generalisasi mengenai pemerolehan bahasa anak. Pada pemerolehan siswa autis terlihat kerumitan dalam menghasilkan kalimat. Struktur kalimat yang dihasilkan siswa autis memiliki pola-pola unik dan beragam jika dilihat melalui proses proyeksi inti leksikal dengan memerhatikan kaidah sintaktik dan kaidah semantik.

Penelitian pemerolehan kalimat bahasa Indonesia yang memanfaatkan teori Tata Bahasa Penguasaan dan Ikatan (selanjutnya disingkat TBPI) ini tidaklah banyak, sebut saja Djiang (1988) dalam disertasinya The Syntactic Passive in Bahasa Indonesia: A Study in Goverment Binding Theory yang memerikan kalimat bahasa Indonesia melalui TBPI yang tidak memiliki penanda kasus, kala,dan agreement sebagai simpulan dalam penelitiannya; Ruddyanto (1994) dalam tesisnya yang berjudul Focus Creation in Indonesia Yes/No Question yang mendapatkan simpulan bahwa kalimat tanya ya/tidak dalam bahasa Indonesia memiliki perbedaan distingtif pada penggunaan penanda kalimat tanya dan urutan kata dengan mengajinya menggunakan TBPI; dan Ghazali (1999) dalam disertasinya yang berjudul Sentence Complexity of the Elementary School Students yang menunjukkan adanya kerumitan kalimat berupa penggunaan keterangan tambahan berbentuk FP atau Fkomp, penambahan komplemen, pemakaian pengomplemen, dan penggunaan struktur koordinasi atau kombinasi . dalam kalimat bahasa Indonesia yang dihasilkan siswa SD.

Tata Bahasa Penguasaan dan Ikatan (TBPI) merupakan pengembangan dari pikiran Chomsky. Pendukung TBPI menjelaskan bahwa salah satu tujuan teori linguistik Chomsky adalah menetapkan piranti Tata Bahasa Semesta yang memiliki struktur umum atas seperangkat sistem kaidah (berhubungan dengan leksikon, sintaksis, dan komponen interpretif) dan sistem yang mengatur prinsip-prinsip nantinya bersamaan menetapkan tata bahasa inti. Dalam TBPI terdapat 4 tingkatan representasi, yakni struktur batin, struktur lahir, bentuk fonetik dan bentuk logis. Tata bahasa dalam TBPI memiliki 7 komponen yang berisikan prinsip dan parameternya dan bersifat moduler menurut pembagian Cook (1988:31) dan Muadz (1991:10), yakni (1) Teori X-Bar, (2) Teori Penguatan, (3) Teori Kasus, (4) Teori Theta, (5) Teori Ikatan, (6) Teori Bounding, dan (7) Teori Kontrol. Menurut Muadz (1991:11) TBPI dianggap lebih memainkan peran penting dalam menentukan dan membuat karakteristik piranti bahasa manusia dibandingkan dengan teori transformasi sebelumnya, karena TBPI ditandai dengan adanya pergeseran fokus dari studi terhadap sistem kaidah ke sistem prinsip. Dalam TBPI, kerumitan sintaksis diakibatkan oleh interaksi antara sub sistem gramatikal seperti: (1) 
Teori Bounding mengatur batas kaidah perpindahan konstituen, (2) Teori Theta mengatur fungsi peran tema, (3) Teori Kasus menyangkut pemakaian kasus abstrak dan realisasi morfologisnya, dan (4) Teori X-Bar yang membatasi komponne dasar sebuah tata bahasa. Penelitian ini berfokus pada teori X-Bar sebagai sub-sistem sintaksis yang digunakan dalam menganalisis data penelitian.

Penelitian lainnya banyak yang menghubungkan TBPI dengan bahasa daerahnya, misalnya Joko Hafrianto dan Mulyadi (2014) dalam artikelnya yang berjudul Kalimat Tanya dalam Bahasa Melayu Dialek Tamiang yang menggunakan teori X-Bar sebagai kajian sintaksis generatif dan mendapatkan simpulan bahwa jenis kalimat tanya total dalam bahasa Melayu dialek Tamiang memerlukan jawaban ya atau tidak dan kalimat tanya parsial memerlukan jawaban penjelas dan keterangan; Sembiring dan Mulyadi (2019) dengan menganalisis tipe predikat kompleks bahasa Karo dan mendapatkan simpulan bahwa melalui teori X-Bar struktur predikat kompleks di bangun oleh specifier yang diduduki oleh NP, complemen yang diduduki oleh auxiliary, PP atau NP, dan adverbia dapat diduduki oleh PP atau NP, dan Zahra dan Mulyadi (2019) dalam artikelnya dengan judul Kalimat Tanya dalam Bahasa Mandailing: Teori X-Bar dengan hasil bahwa kalimat tanya pada bahasa Mandailing memiliki fungsi gramatikal specifier dan komplemen.

Penelitian ini memusatkan pada pemerolehan kaidah sintaksis dalam perkembangan kerumitan kalimat bahasa Indonesia siswa autis dengan memilih sejumlah frasa dan kalimat yang dihasilkan siswa autis. Kerumitan kalimat siwa autis ini diamati melalui proses proyeksi inti leksikal dengan memerhatikan kaidah sintaktik dan kaidah semantik. Kebaharuan dalam penelitian ini adalah akan didapatkannya pola frasa maupun kalimat yang dihasilkan siswa autis. Jika pada siswa normal lainnya akan menghasilkan banyak pola kalimat, maka pada siswa autis akan terbatas dalam kalimat yang dihasilkan dan tentu saja dengan pola yang khas. Seperti penelitian yang telah dilakukan Ghazali (2004) yang melihat pertumbuhan kalimat BI siswa SD dapat dipilah menjadi dua golongan besar, yaitu: (1) kalimat yang tumbuh dari inti leksikal, dan (2) kalimat yang tumbuh dari inti fungsional. Pemerian dilakukan dengan memperlihatkan proyeksi bertahap inti leksikal dari tataran proyeksi inti leksikal $\left(\mathrm{X}^{0}\right)$ sampai proyeksi maksimal $\left(\mathrm{X}^{\max }\right)$, sehingga terlihat berapa inti, komplemen, dan keterangan tambahan (adjunct). Untuk mendeskripsikan pemerolehan bahasa yang dihasilkan siswa autis, peneliti menggunakan TBPI yang dikembangkan oleh Chomsky, khususnya skema X-Bar. Selanjutnya kerumitan kalimat tersebut akan dieksplanasikan mulai dari kalimat yang paling sedikit melibatkan inti (head) sampai yang paling banyak. Dari urutan tersebut akan diketahui perbedaan kerumitan kalimat yang satu dengan yang lainnya mulai dari penetapan inti leksikalnya, unsur yang terlibat dalam proses proyeksi dan menggambarkan proyeksi kalimat tersebut melalui diagram pohon yang dapat memberikan kejelasan tentang kerumitan kalimat yang diperikan.

\section{TEORI X-BAR}

Teori X-Bar adalah teori struktur frase sebuah kalimat di tingkat struktur batin ( $d$ structure) yang mengandung beberapa prinsip umum dan sederhana yang mengatur atau 
menjelaskan struktur internal sebuah bahasa. Teori ini berusaha menerapkan prinsipprinsip umum Tata Bahasa Semesta, sehingga penerapan teorinya dapat bersifat kategori silang dalam suatu bahasa tertentu maupun antarbahasa. Teori dasar yang terkandung dalam teori X-Bar ini ialah bahwa apabila seseorang mengamati sebuah frase yang berbeda akan ditemukan kesamaan secara internal frase yang pada permukaannya tampak berbeda tersebut.

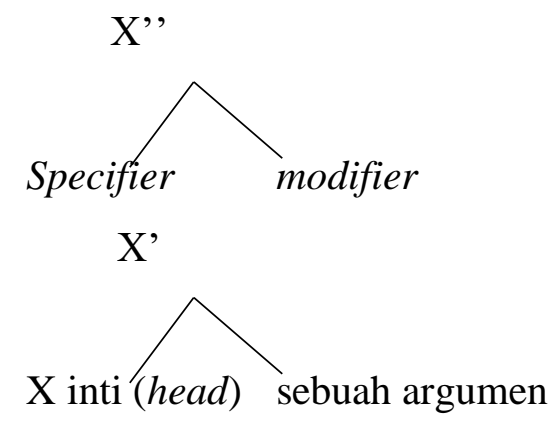

Gambar 1. Skema X-Bar (diadaptasi dari Ghazali, 2004)

Teori X-Bar yang berkembang akhir-akhir ini mengemukakan generalisasi mengenai konstituen frase, yakni bahwa sebuah struktur frase selalu mempunyai inti (head) dan komplemen yang bergantung pada kepadanya. Apabila sebuah inti frase dilambangkan dengan kode $\mathrm{X}$, maka konstituen yang lebih besar disebut dengan X ( XBar) atau X-berpalang satu (selanjutnya simbol X-berpalang satu akan diketik dengan $X^{\prime}$ ), sedangkan $X$ berpalang dua akan diketik $X$ '. Dengan konsep seperti ini maka digambarkan bisa saja sebuah verba 'makan' (V) akan menjadi V' apabila kata tersebut berubah menjadi konstituen yang lebih besar, misalnya 'makan pepaya mentah' dan V' akan menjadi V', apabila V' tersebut mendapatkan keterangan 'yang ia beli di pasar Jalan Jombang', sehingga V' yang merupakan proyeksi maksimal dari V, berupa sebuah konstruksi 'makan pepaya mentah yang dia beli di pasar Jalan Jombang'. Begitupun yang terjadi pada kata berkategori sifat, kata depan, atau kata dengan kategori apapun (Ghazali, 1999:68-69).

\section{METODE PENELITIAN}

Penelitian ini bertujuan mengaji kerumitan bahasa Indonesia siswa autis. Untuk mencapai tujuan itu, penelitian ini menggunakan tuturan kalimat yang dihasilkan siswa autis dalam melakukan interaksi dengan guru melalui tanya jawab. Setiap unsur kalimat yang menandai pemerolehan kerumitan kalimat diangkat sebagai korpus yang pada gilirannya dapat diamati, dideskripsikan dan dijelaskan. Penelitian ini adalah penelitian kualitatif, pendekatan studi kasus. Karakteristik penelitian kualitatif tampak pada ciri data, sumber data, teknik pengumpulan data dan teknik analisis data. Data penelitian ini berupa tuturan lisan siswa autis dan guru autis sebagai data verbal yang disertai konteks tuturan. Catatan lapangan digunakan sebagai tambahan data verbal dan nonverbal. Data verbal terdiri dari tuturan siswa autis ketika bertutur dalam proses pembelajaran terutama ketika proses tanya jawab dengan guru. Wujud data berupa kalimat yang dihasilkan anak autis sesuai konteks yang menyertai tuturan tersebut. Data verbal diperoleh melalui 
observasi dengan dibantu alat perekam (audio visual) dan catatan lapangan. Data verbal yang diperoleh dari rekaman, selanjutnya ditranskripsikan dan diklasifikasikan berdasarkan fokus penelitian, kemudian dimasukkan dalam instrumen pengumpul data. Setelah hasil data terkumpul dengan baik, data hasil rekaman maupun data hasil catatan lapangan, kemudian ditranskripsikan dan dianalisis sementara untuk memperoleh gambaran sesuai fokus penelitian. Selanjutnya, jika data sudah diperoleh secara keseluruhan, masing-masing data dipilah dan diberikan kode sesuai dengan pemanfaatan analisis. Data yang digunakan merupakan hasil pengumpulan data dari penelitian terdahulu yang telah dilakukan peneliti sebelumnya dan akan digunakan sebagai sumber data dengan kajian yang berbeda. Sumber data dalam penelitian ini adalah siswa autis yang bersekolah di SLB Autis Laboratorium Universitas Negeri Malang yang diwakili lima orang siswa di kelas akademik.

\section{PEMBAHASAN}

\section{Kalimat Bahasa Indonesia pada Siswa Autis yang Dikembangkan dengan Inti Leksikal}

Kata yang berkategori $\mathrm{X}$ dapat berproyeksi ke posisi yang lebih tinggi dengan menjadi frase pada masing-masing kategori dalam inti leksikal, misalnya inti leksikal verba dapat menurunkan frase verba $(\mathrm{FV})$, inti leksikal adjektiva dapat menurunkan frase adjektiva (FAdj), dan seterusnya. Penambahan kategori dapat didasarkan pada persyaratan pemilihan kategori dan pemilihan unsur berdasarkan kesesuaian makna hingga mencapai proyeksi maksimal (X'). Tidak ditemukan proyeksi inti leksikal nomina, preposisi, dan lainnya. Proyeksi inti leksikal verba dan adjektiva dari kalimat yang dihasilkan siswa autis dapat diuraikan berikut.

\section{A. Kalimat dengan inti leksikal verba}

Inti leksikal verba dapat berproyeksi dengan adanya penambahan komplemen dan keterangan lainnya atau tanpa penambahan unsur tergantung pada informasi yang disajikan dalam kalimat tersebut. Kalimat yang dihasilkan siswa autis biasanya berupa kalimat sederhana yang terdiri dari satu kata, tetapi tidak menutup kemungkinan ditemukan kalimat yang dihasilkan berupa dua atau tiga kata. Keterlambatan atau kesulitan dalam perkembangan bahasa kemudian akan muncul sebagai bagian dari masalah yang lebih luas dalam memikirkan pemikiran yang tidak terpikirkan dan dalam representasi mengirimkan pengalaman emosional secara simbolis (Cathy, 2002:74). Berikut analisis kalimat dengan inti leksikal verba yang memiliki pola tanpa komplemen, inti leksikal verba dengan adanya argumen dalam, inti leksikal dengan keterangan tambahan frase preposisi, dan koordinasi verba berpalang satu (V' coordination).

\section{Kalimat dengan inti leksikal verba tanpa komplemen}

Kalimat yang dihasilkan siswa autis berupa kalimat yang dihasilkan dari inti leksikal verba tanpa komplemen. Inti leksikal verba ini terdapat dalam data berikut:

(1) Dito bermain. (T1/DT95/Im) 
(2) Dia masak. (T3/DT89/Dv)

Inti leksikal verba bermain dan masak adalah inti leksikal verba yang dapat berproyeksi maksimal menjadi frase verba (FV) tanpa adanya kehadiran konstituen lain. Pada kalimat tersebut verba berupa predikat satu tempat, yakni verba yang tidak memerlukan adanya komplemen atau argumen dalam. Tidak diperlukannya argumen dalam karena inti leksikal verba bermain dan masak adalah inti leksikal yang hanya dapat memberikan sebuah peran teta, yakni peran pelaku (agent) aktivitas yang terkandung dalam inti leksikal tersebut. Meskipun tidak adanya komplemen pada kalimat yang dihasilkan siswa autis tersebut dikatakan sudah memenuhi persyaratan prinsip proyeksi. Struktur frase datam teori X-bar bertalian dengan tiga fungsi gramatikal, yakni komplemen (Komp.), keterangan (Ket.), dan spesifier (Spes.) (Mulyadi, 2010:1)

Secara semantis, verba bermain dan masak memerlukan argumen luar berupa manusia yang bertindak sebagai pelaku (agent) dan pihak pelaku perbuatan (experiencer) dari verba tersebut. Maka kalimat tersebut dapat dikatakan sebagai kalimat yang berterima dengan adanya kesesuaian antara inti dengan specifier-nya (specifier-head agreement). Inti leksikal bermain dan masak memiliki sebuah FN sebagai argumen luarnya yang pada kalimat tersebut berkedudukan sebagai subjek kalimat sebagai pelaku atau menjadi pihak yang mengalami pekerjaan atau tindakan. Maka kehadiran FN Dito dan dia sudah sesuai dengan tuntutan inti leksikal verba dalam kalimat tersebut secara semantis dan sintaksis.

Proses proyeksi inti leksikal verba dapat dilihat dalam diagram pohon berikut ini.

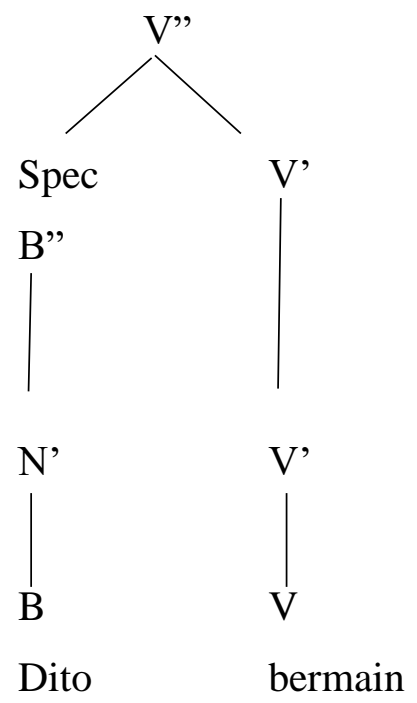

Pada diagram pohon tersebut terlihat bahwa inti leksikal verba bermain dapat berproyeksi ke tingkat proyeksi maksimal (V") yang memperlihatkan bahwa V naik tingkat proyeksi V' tanpa adanya konstituen lainnya. Kalimat dia masak mempunyai struktur internal yang sama sehingga dapat digambarkan pada diagram yang sama. Dalam kalimat yang dihasilkan siswa autis tidak ditemukan inti leksikal verba tanpa komplemen dengan argumen FN berupa benda bukan manusia. Ditemukan kalimat yang tumbuh dari inti leksikal verba dengan gabungan FN sebagai argumennya, yakni 
(3) Helikopter, pesawat, roket terbang. (T6/DT67/Dv)

Kalimat tersebut dibentuk dari inti leksikal verba yang tidak memerlukan argumen dalam meskipun struktur kalimat tidak sesuai karena kata rujukan terbang seharusnya menjadi beterbangan. Perbedaannya terletak pada argumen luar yang berbentuk koordinasi frase nomina, maka akan terlihat pada diagram struktur batin berikut.

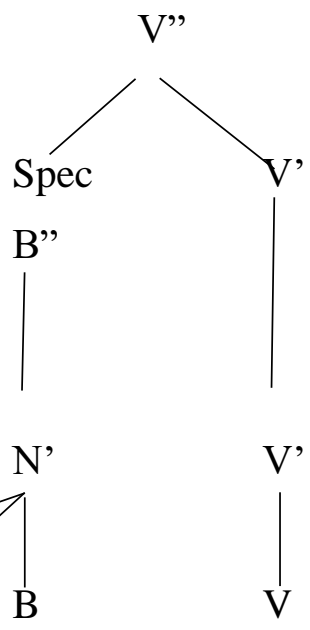

Helikopter, pesawat, roket terbang

Pada diagram tersebut terlihat bahwa FN yang berkedudukan sebagai specifier dari inti leksikal verba terbang atau beterbangan terbentuk dari koordinasi frase nomina. Pemerolehan kalimat pada siswa autis dihasilkan dengan pola sederhana melalui pendampingan guru agar dapat menghasikan kalimat yang produktif. Siswa dengan inisial Dv lebih banyak menghasilkan kalimat yang lengkap dibandingkan siswa lainnya.

\section{Kalimat dengan inti leksikal verba dengan adanya argumen dalam}

Bagian ini akan dipaparkan kalimat yang dibangun dari inti leksikal verba dengan adanya komplemen sebagai argumen dalam. Kalimat berikut akan memperlihatkan inti leksikal verba yang mengandung komponen-komponen kalimat yang dimaksudkan.

(4) Ina menyapu teras. (T1/DT97/Im)

(5) Dia ngelon adik. (T3/98/Dv)

Pada kalimat tersebut terdapat inti leksikal verba menyapu dan ngelon (arti menurut KKB daring adalah kelon atau mengeloni berasal dari bahasa Jawa yang berarti memeluk (anak dan sebagainya) dengan kasih sayang sambil berbaring supaya tidur). Inti leksikal tersebut memerlukan kehadiran argumen dalam dan luar dengan peran theta yang berbeda. Inti leksikal verba tersebut memerlukan argumen dalam sebagai penerima pesan theta tujuan dan argumen luar sebagai penerima peran theta pelaku perbuatan. Inti leksikal menyapu memerlukan kehadiran FN teras sebagai argumen dalamnya, sedangkan kata ngelon memerlukan FN adik. Frase nomina tersebut wajib hadir mengikuti inti leksikal verba menyapu dan ngelon, sehingga jika tidak hadir kalimat tersebut tidak akan berterima. Peran FN yang mengikuti inti leksikal verba tersebut adalah penerima peran theta tujuan. Maka kehadiran FN teras dan adik telah sesuai dengan 
persyaratan pemilihan konstituen (c-select) inti leksikal verbanya. Beberapa orang dengan autisme dapat membuat hubungan yang lebih lemah antara representasi fitur dalam memori semantik (Ian, 2020:107).

Proses proyeksi inti leksikal verba dengan argumen dalam kalimat (4) dan (5) dapat digambarkan dengan struktur-D berikut

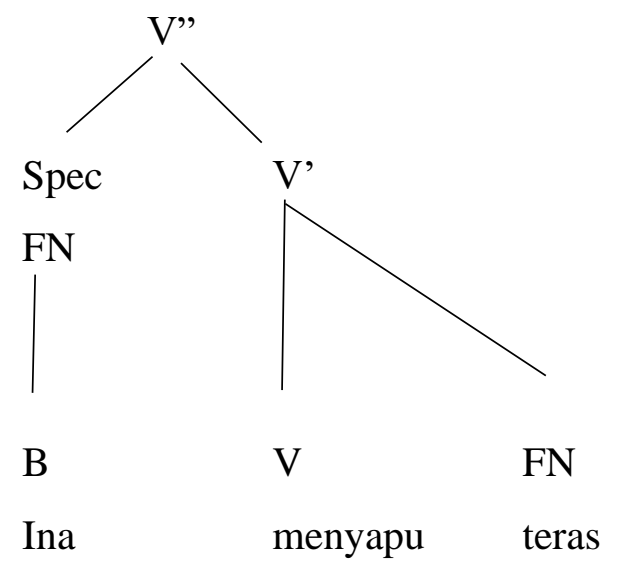

Diagram pohon tersebut memperlihatkan inti leksikal verba menyapu berproyeksi ke tataran V' yang memerlukan kehadiran FN sebagai argumen dalam, yakni teras untuk selanjutnya $\mathrm{V}$ ' memerlukan argumen luar berupa $\mathrm{FN}^{2}$ untuk menuju ke proyeksi maksimal yang pada gilirannya mendapatkan peran theta pelaku. Proyeksi leksikal maksimal pada diagram di atas menghasilkan kalimat yang berterima secara sintaksis maupun semantis. Demikian juga kalimat (5) proses proyeksinya dapat digambarkan seperti pada diagram di atas meskipun verba berasal dari istilah dalam bahasa Jawa. Tidak ditemukan kalimat inti leksikal verba dengan dua buah argumen dalam dikarenakan kemampuan siswa autis dalam memproduksi tuturan sangat terbatas.

\section{Kalimat dengan inti leksikal keterangan tambahan frase preposisi}

Siswa autis juga dapat menghasilkan beberapa kalimat dengan inti leksikal verba yang berproyeksi ke peringkat V" dengan adanya penambahan keterangan tambahan frase preposisi (FP). Proyeksi inti leksikal verba tersebut dapat dilihat dalam kalimat berikut.

(6) Aku pergi ke Batu. (T6/DT109/Az)

(7) Orang bekerja di rumah. (T2/DT55/Dv)

Inti leksikal verba tersebut memiliki predikat satu tempat, sehingga dapat berproyeksi ke tataran V' dengan tambahan FN yang berada di bawah specifier yang dapat diberi peran pelaku perbuatan. Kalimat aku dan orang adalah FN yang melaksanakan perbuatan dalam predikat tersebut dan dapat berperan sebagai theta pelaku perbuatan. Proyeksi inti leksikal verba dengan argumen luar masih dapat ditambahkan dengan keterangan tambahan (adjunct) berupa frase preposisi agar dapat berproyeksi ke tataran yang lebih tinggi, misalnya pada keterangan tempat, waktu, cara, atau tujuan. Pada kalimat (6) inti leksikal verba pergi mendapatkan keterangan tempat ke Batu dan kalimat (7) dengan inti leksikal bekerja mendapatkan keterangan tempat ke Batu sehingga inti leksikal verba menjadi FV pergi ke Batu dan bekerja di rumah. Proyeksi inti leksikal 
verba yang mencapai proyeksi maksimal dapat digambarkan dengan diagram struktur-D berikut.

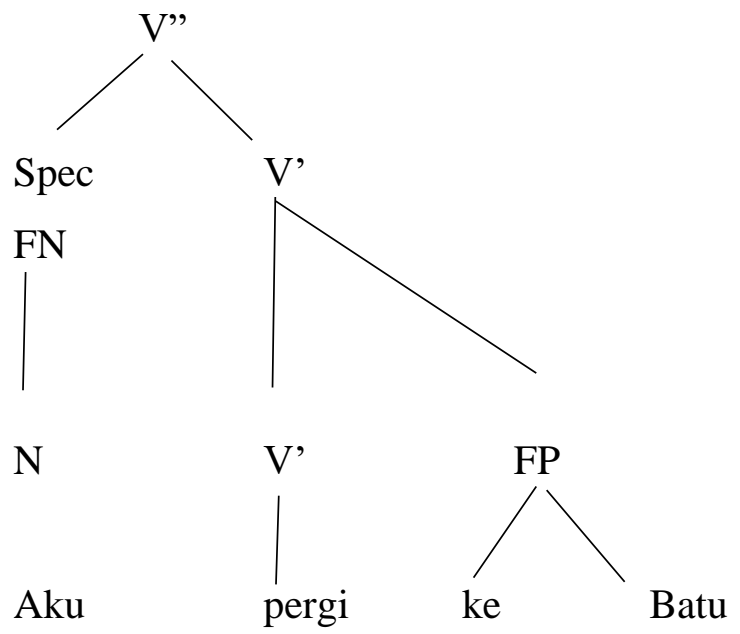

Diagram pohon di atas memperlihatkan bahwa $\mathrm{V}$ berproyeksi ke peringkat V' tanpa penambahan konstituen, akan tetapi inti leksikal verba $V^{\prime}$ diproyeksikan lagi ke V' simpul kedua karena $V^{\prime}$ mendapatkan keterangan tambahan berupa keterangan tempat. Unsur yang berpadu dalam V' bergerak untuk mendapatkan specifier. Kelompok data lainnya memiliki struktur internal yang sama. Tidak ditemukan inti leksikal verba dengan keterangan tambahan dua buah preposisi dalam kalimat yang dihasilkan siswa autis.

\section{Kalimat dengan koordinasi verba berpalang satu ( $\mathrm{V}$ ' coordination)}

Siswa autis dapat menghasilkan kalimat yang mengordinasikan beberapa inti leksikal dengan argumen dalam seperti pada kalimat

(8) Mama belanja sayur, naik mobil, setrika baju. (T2/DT12/Ri)

(9) Aku bangun tidur, makan pagi, potong rambut. (T2/DT104/Dv)

Kalimat tersebut dibangun dari tiga buah inti leksikal verba dengan predikat dua tempat, yakni belanja, naik, setrika pada kalimat (8) dan bangun, makan, potong pada kalimat (9) yang memerlukan argumen dalam. Argumen yang diperlukan adalah FN seperti pada kalimat (8) sayur, mobil, baju dan kalimat (9) terdapat kalimat tidur, pagi, dan rambut yang secara semantis dapat menerima peran sebagai penerima dan juga dapat menjadi objek dari inti leksikal verba tersebut. Inti leksikal verba tersebut terdiri dari tiga buah yang berada dalam satu kalimat. Dengan demikian ketiga inti leksikal bersama dengan argumen dalamnya berproyeksi ke simpul V' secara bersama-sama, namun dalam kalimat tersebut tidak dihubungkan dengan konjungsi dan. Simpul V' yang terbentuk adalah belanja sayur, naik mobil, setrika baju, bangun tidur, makan pagi, dan potong rambut. Pada tahap proyeksi selanjutnya, simpul pertama V' memerlukan specifier agar V' dapat berproyeksi secara maksimal ke tingkat V', Specifier yang hadir adalah sebuah FN, yakni mama pada kalimat (8) dan $a k u$ pada kalimat (9). Pelaku yang diperlukan ketiga $V^{\prime}$ 'akan dilakukan reduksi sehingga FN yang muncul sebagai penerima peran sebagai subjek hanya satu saja. Pada proses proyeksi inti leksikal verba tersebut bahwa 
V', proyeksi maksimal dari inti leksikal verba tetap dapat menghasilkan kalimat yang berterima. Hal tersebut dapat dilihat melalui diagram pohon berikut.

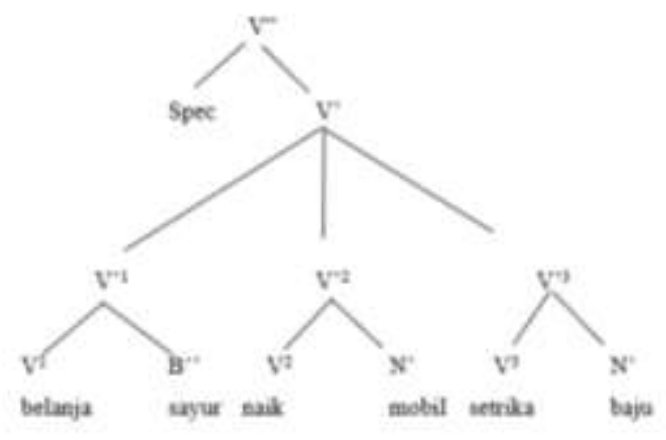

Pada diagram pohon terlihat bahwa masing-masing inti leksikal verba tumbuh menjadi V' karena masing-masing inti leksikal memperoleh komplemen FN. Inti leksikal verbanya adalah predikat dua tempat, berarti inti leksikalnya termasuk inti yang menuntut kehadiran dua buah FN sebagai argumennya. Sebuah FN sebagai penerima peran sebagai tema, sedangkan FN yang lain sebagai penerima peran pelaku perbuatan yang terkandung dalam predikat tersebut. Frase nomina yang mendapatkan peran sebagai pelaku perbuatan yang terdapat dalam predikat adalah mama. Terlihat bahwa proyeksi berjalan sempurna karena proyeksi maksimal tiga buah inti leksikal verba secara koordinatif bergabung menjadi satu V'. Inti leksikal verba dapat naik ke peringkat V' karena masing-masing inti leksikal mendapatkan argumen dalamnya. Siswa autis telah dapat melakukan generalisasi dengan menggabungkan inti leksikal yang memiliki kategori yang sama meskipun tanpa adanya konjungsi dan untuk kemudian naik ke tingkat proyeksi leksikal dan bertemu di simpul V'.

Kalimat siswa autis yang dikembangkan melalui proyeksi inti leksikal banyak dihasilkan siswa autis dengan ciri-cirinya. Ciri tersebut adalah (1) kalimat yang dibangun dengan inti leksikal verba (V) tanpa komplemen. Dari tataran V' simpul pertama proyeksi berlanjut ke tataran proyeksi maksimal (FV) setelah V' mendapatkan argumen luar berupa frasa benda berupa insan, sehingga memiliki struktur $\mathrm{FV}=\mathrm{V}$; (2) kalimat yang dibangun dengan inti leksikal verba (V) yang berproyeksi ke tataran V' cabang pertama dengan adanya argumen dalam, kemudian V' simpul pertama berproyeksi maksimal dengan specifier dengan frasa berupa insan dengan struktur FV=V FN; (3) kalimat yang dibangun dengan inti leksikal verba (V) yang berproyeksi ke tataran V' cabang pertama dengan keterangan tambahan frase preposisi, sehingga strukturnya menajdi FV=V FN; dan (4) kalimat yang dibangun dengan inti leksikal verba dengan masing-masing argumen dalam yang membentuk koordinasi, sehingga strukturnya menjadi $F V=V$ FN, V FN, V FN. Tipe kalimat yang dihasilkan siswa autis merupakan kalimat yang dibangun dengan inti leksikal verba yang secara bertahap berproyeksi ke tingkat proyeksi maksimal dengan tambahan berbagai unsur seperti argumen dalam, komplemen,atau pun keterangan tambahan. 


\section{B. Kalimat dengan inti leksikal adjektiva}

Paparan pada bagian ini relatif sama dengan penjelasan pada inti leksikal verba. Inti leksikal adjektiva diidentifikasi untuk kemudian diperikan konstituen yang menyertai inti ke tingkat proyeksi maksimal, termasuk di dalamnya berupa komplemen, keterangan tambahan, dan argumen. Inti leksikal adjektiva dapat berproyeksi ke tataran proyeksi maksimal tanpa argumen apapun karena inti leksikal adjektiva tidak dapat memberikan peran kepada unsur lain di dalam kalimat. Inti leksikal adjektiva dapat langsung naik ke tataran FA dan mendapatkan specifier yang diperlukan inti tersebut. Hal tersebut dapat terlihat pada data berikut

(1) Saya capek. (T2/DT89/Ri)

(2) $\mathrm{Bu}$ Vivi cantik sekali. (T1/DT35/Dn)

Kalimat tersebut memiliki sebuah inti leksikal, yakni capek dan cantik. Inti leksikal adjektiva ini tergolong ke dalam inti leksikal yang ketika berproyeksi tidak mempunyai argumen dalam. Unsur yang diperlukan inti FAdj tersebut adalah sebuah FN yang dapat menerima peran theta pengalami (experiencer) dari inti leksikal yang ada. Maka saya dan Bu Vivi adalah FN yang berkedudukan sebagai pihak yang mengalami keadaan psikologi capek dan diikuti kata sifat cantik. Jika dilihat dari hubungan semantis antara predikat dengan argumen luarnya dapat dikatakan bahwa FAdj capek memiliki keselarasan dengan FN saya dan FN Bu Vivi dengan FAdj cantik yang memiliki arti bahwa hubungan antara predikat dan argumen luarnya menghasilkan bentukan yang logis (semantically well-formed). Secara sintaksis, predikat capek dan cantik memerlukan konstituen yang berkategori FN dan FN yang diperlukan adalah dapat menerima kedudukan sebagai subjek sebagaimana yang terdapat pada data, yakni FN saya dan $b u$ Vivi adalah FN yang menduduki subjek. Kehadiran FN yang tepat dapat menghasilkan kalimat yang berterima. FAdj capek dan cantik merupakan inti leksikal yang dapat langsung berproyeksi ke tataran A' karena inti leksikalnya tidak memerlukan argumen apapun. Namun pada data (2) terdapat unsur yang menyertai predikat, yakni sekali, sehingga dari tataran Adj' inti leksikal dapat langsung berproyeksi ke tataran proyeksi maksimal (FAdj) setelah inti mendapatkan specifier. Dalam struktur D-nya, FN dapat naik ke posisi specifier yang ada di posisi FI, maka FN bu Vivi mendapatkan kasus dari I yang dapat diihat pada diagram pohon berikut. 


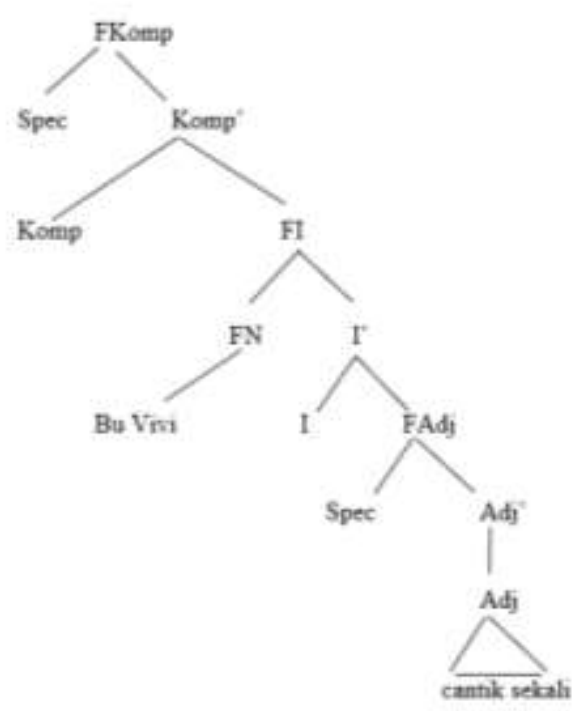

Proses proyeksi tersebut memperlihatkan bahwa masing-masing unsur yang diperlukan oleh konstruksi predikat satu tempat telah sesuai dengan kategori dan makna yang dipersyaratkan, sehingga menghasilkan kalimat yang berterima. Jika dihadirkan argumen dalam akan menghasilkan kalimat yang tidak berterima. Kalimat yang dibangun dari inti leksikal adjektiva mempunyai ciri tersendiri. Inti leksikal adjektiva dapat berproyeksi maksimal atau tumbuh menjadi kalimat lengkap dan memperoleh keterangan tambahan dan komplemen. Pada tataran ini, kalimat yang dihasilkan siswa autis sangat sederhana dan terbatas. Siswa autis hanya dapat menghasilkan ciri inti leksikal adjektiva, yakni dengan kalimat tanpa argumen yang berproyeksi maksimal dan diproyeksikan langsung ke proyeksi maksimal (FAdj) setelah inti leksikal ini mendapatkan sebuah argumen luar berupa FN insan dengan struktur kalimat Fadj=Adj. Namun, karena adjektiva tidak dapat memberikan kasus kepada specifier-nya maka dilakukan pemindahan unsur FN ke simpul yang berada di bawah kekuasaan FI. Perpindahan ini membuat proyeksi maksimal inti leksikal adjektiva berupa FKomp yang menghasilkan struktur D-nya menjadi FKomp=Komp' [Komp FI [I Fadj [Adj'[Adj]]]]].

Jika dilihat berdasarkan data yang dikemukakan, siswa autis lebih banyak mengembangkan inti leksikal verba daripada inti leksikal lainnya. Tuturan kalimat yang dihasilkan siswa diidentifikasi menjadi satu kalimat meskipun terdapat jeda waktu dalam menuturkannya. Kemampuan siswa yang berbeda menghasilkan kalimat yang berbeda pula. Inti leksikal verba tanpa argumen dalam banyak dijumpai pada kalimat yang dihasilkan siswa autis. Dalam proses proyeksi menuju proses terjadi gejala peningkatan penggunaan keterangan tambahan, struktur koordinasi pada proyeksi leksikal, maupun pengomplemen di tataran FN. Didapatkan juga penggunaan FKomp sebagai keterangan tambahan pada kalimat yang dihasilkan siswa pada inti leksikal verba. Temuan ini menunjukkan bahwa semakin banyak proses proyeksi, maka akan semakin tinggi tingkat kerumitan yang dihadapi siswa autis terutama siswa yang berada di kelas tinggi ini. Selain itu, pada tataran inti leksikal yang memiliki tataran V' cabang kedua dan ketiga mendapatkan keterangan tambahan dan pada specifier. Siswa telah dapat menggunakan pengomplemen, baik sebagai komplemen maupun keterangan tambahan. Penelitian Sari 
(2014) menunjukkan bahwa terdapat tiga hal yang terdapat pada struktur kalimat anak autis, yakni kalimat yang tersusun satu fungsi kalimat dalam kalimat satu kata, kalimat yang tersusun dua fungsi kalimat dalam kalimat dua kata, dan kalimat yang tersusun tiga fungsi kalimat dalam kalimat tiga kata. Dalam penelitian ini kalimat yang dihasilkan siswa bervariasi dilengkapi dengan inti leksikal verba dan adjektiva masing-masing. Meskipun siswa berada di kelas tinggi dengan usia 9-15 tahun akan menghasilkan kalimat yang beragam.

Berdasarkan perkembangan kognitif dengan munculnya proyeksi inti leksikal verba yang dominan diperoleh pada kalimat siswa autis merupakan hal yang menarik. Menurut Piaget pada tahap perkembangan anak terutama di usia jenjang kelas 4,5 dan 6 berada pada perkembangan operasi kongkrit. Terutama ketika ini dihasilkan pada siswa autis yang memiliki keterbatasan dalam menghasilkan tuturan, karena umumnya anak autis hanya dapat menghasilkan satu atau dua kata saja dalam tuturannya. Mereka mengalami lebih banyak kesulitan menggunakan dan menggabungkan unsur-unsur linguistik tertentu untuk membangun dan menyampaikan wacana naratif yang koheren (Philippine, 2021:2). Siswa autis menghasilkan lebih banyak kata, urutan sintaksis, dan unit sintaksis secara keseluruhan. Hal ini adalah pola hasil dalam produktivitas tuturan mendukung asumsi bahwa produksi naratif adalah tugas yang sulit dan menuntut bagi individu autis, bahkan lebih dari percakapan (Botting, 2002). Inti leksikal verba yang dominan membuat siswa autis dilatih untuk bernalar sekaligus memperkuat kaidah tatabahasanya. Pada tingkat proyeksi maksimal, kalimat yang dihasilkan siswa berasal dari inti leksikal satu tempat, dua tempat, dan keterangan tambahan berupa sebuah frase yang merupakan proses proyeksi yang lazim ditemukan pada anak umum, tetapi menjadi sangat menarik ketika dapat dihasilkan anak autis dalam pemerolehan bahasanya. Siswa autis mampu menghasilkan kalimat dengan memanfaatkan pengetahuan kebahasaan dalam otaknya sesuai teori Chomsky (1986) untuk menghasilkan kalimat yang berterima secara sintaksis dan semantis. Dengan menggunakan intuisi linguistiknya, siswa autis menghasilkan kalimat dengan tingkat kerumitan dari tahap sederhana sampai tahap yang rumit untuk siswa autis. Hal tersebut nampak dalam proses proyeksi dari tataran inti leksikal menuju tataran proyeksi maksimal melalui unsur inti leksikal, komplemen, dan specifier.

\section{SIMPULAN}

Penelitian ini menemukan bahwa siswa autis dengan jenjang SD yang terbagi dalam kelas 4,5, dan 6 dapat mengembangkan kerumitan kalimat dengan menggunakan inti leksikal verba dan adjektiva. Inti leksikal verba yang memiliki pola tanpa komplemen, inti leksikal verba dengan adanya argumen dalam, inti leksikal dengan keterangan tambahan frase preposisi, dan koordinasi verba berpalang satu (V' coordination) ditemukan pada kalimat yang dituturkan siswa autis dalam menjawab pertanyaan guru. Inti leksikal adjektiva berupa kalimat tanpa argumen yang berproyeksi maksimal dan diproyeksikan langsung ke proyeksi maksimal (FAdj). Temuan ini memiliki kontribusi bagi teori kognitif dan pengajaran bahasa. 


\section{UCAPAN TERIMA KASIH}

Peneliti mengucapkan terima kasih yang sebesar-besarnya kepada LPPM Universitas Muhammadiyah Jember atas pendanaan kegiatan Penelitian Stimulus Tahun 2021 ini hingga berjalan sangat baik.

\section{DAFTAR RUJUKAN}

Botting, N. (2002). Narrative as a Tool for the Assessment of Linguistic and Pragmatic Impairments. Child Language Teaching and Therapy, 18(1), 1-21. https://doi.org/10.1191/0265659002ct224oa

Cathy Urwin (2002) A Psychoanalytic Approach to Language Delay: When Autistic isn't Necessarily Autism, Journal of Child Psychotherapy, 28:1, 73-93, DOI: $\underline{10.1080 / 00754170110114800}$

Cook, V. (1988). Chomsky Universal Grammar:An Introduction. New York: Basil Blackwell Inc

Ghazali, (1999). Kerumitan Kalimat Bahasa Indonesia Siswa Sekolah Dasar. Disertasi tidak diterbitkan. Institut Keguruan dan Ilmu Pendidikan Malang

Ghazali. (2004). Perkembangan Kerumitan Kalimat Bahasa Indonesia Siswa SD. Bahasa dan Seni, tahun 32, nomor 2, Agustus 2004.

Hafrianto, Joko, \& Mulyadi. (2018). Kalimat Tanya dalam Bahasa Melayu Dialek Tamiang. LITERA. Vol. 17, Nomor. 2

Hare, I. (2020). Semantic Feature Dissociation: A New Hypothesis Concerning Autism, Philosophical Psychology, 33:1, 102-124, DOI: $\underline{10.1080 / 09515089.2019 .1683728}$

Lam, Y., \& Yeung, S. (2012). Towards A Convergent Account Of Pragmatic Language Deficits In Children With High-Function-Ing Autism: Depicting The Phenotype Using The Pragmatic Rating Scale. Research in Autism Spectrum Disorders, 6(2), 792-797. doi:10.1016/j.rasd.2011.08.004

M. M. Mulyadi, (2012). "Frase Preposisi Bahasa Indonesia: Analisis X Bar," Kajian Sastra, vol. 34, No. 1, pp. 1-12, Mar.

Muadz, H. (1991). Coordinate Structure: A Planar Representation. Disertasi tidak diterbitkan. Arizona: The University of Arizona 
Permata, B. A. (2015). Teori Generatif-Transformatif Noam Chomsky Teori GeneratifTransformatif Noam Chomsky dan Relevansinya dalam Pembelajaran Bahasa Arab. Empirisma. Vol. 24 No. 2 Juli 2015, p. 179-187

Geelhand, P., Papastamou, F., \& Kissine, M. (2021) How do autistic adults use syntactic and prosodic cues to manage spoken discourse?, Clinical Linguistics \& Phonetics, DOI: $10.1080 / 02699206.2021 .1878278$

Sari, P. (2014). Kalimat Bahasa Indonesia Anak Autis di Sekolah Autis Lab UM. Skripsi tidak Diterbitkan. Pendidikan Bahasa, Sastra Indonesia dan Daerah. Fakultas Sastra. Universitas Negeri Malang.

Sembiring, Hariati, \& Mulyadi. (2019). Predikat Kompleks Bahasa Karo:Kajian X-Bar. LINGUA: Jurnal Bahasa dan Sastra. Vol.15, No.2

Zahra, \& Mulyadi. (2019). Kalimat Tanya dalam Bahasa Mandailing: Teori X-Bar. RETORIKA. Jurnal Bahasa, Sastra, dan Pengajaran. Vol. 12, No.2 
